\title{
Caso Arrom Suhurt Y Otros Vs. Paraguay
}

Sentencia de 13 de mayo de 2019

El 13 de mayo de 2018 la Corte Interamericana de Derechos Humanos (en adelante "la Corte" o "este Tribunal") dictó una Sentencia mediante la cual declaró que el Estado de Paraguay no es responsable por la violación de: (i) los artículos 3, 4, 5 y 7 de la Convención Americana en relación con el artículo I.a) de la Convención Interamericana sobre Desaparición Forzada de Personas y los artículos 1 y 6 de la Convención Interamericana para Prevenir y Sancionar la Tortura; (ii) la violación de los artículos y 25.1 de la Convención Americana en relación con el artículo 1.1 del mismo instrumento, el artículo I.b) de la Convención Interamericana sobre Desaparición Forzada de Personas y de los artículos 1, 6, y 8 de la Convención Interamericana para Prevenir y Sancionar la Tortura, y (iii) la violación del artículo 5 en relación con el artículo 1.1 de la Convención Americana. Al no haberse establecido la responsabilidad internacional del Estado, el Tribunal consideró que no procedía pronunciarse sobre reparaciones, costas y gastos.

\section{Hechos}

De acuerdo a lo declarado por Juan Arrom y Anuncio Martí, el 17 de enero de 2002 a las 22:00 horas fueron detenidos por hombres armados vestidos de civiles, quienes los habrían golpeado, asfixiado e interrogado sobre el secuestro de la señora María Edith Bordón y la organización Patria Libre. Habrían permanecido detenidos hasta el 30 de enero, cuando fueron encontrados en una casa en Villa Elisa. Tras su liberación, Juan Arrom y Anuncio Martí identificaron como sus captores a diversos agentes estatales. 
El Estado tomó conocimiento de la alegada desaparición a través de los recursos de hábeas corpus interpuestos por los familiares de Arrom Suhurt y Martí Méndez, el 19 y 23 de enero de 2002, respectivamente. Los jueces que conocieron de los recursos libraron oficios al Ministerio del Interior y a la Policía Nacional a fin de que informaran si Juan Arrom Suhurt y Anuncio Martí se encontraban detenidos. Tras recibirse información sobre que no se encontraban detenidos, los hábeas corpus fueron negados, teniendo en cuenta además que existía una orden de detención pendiente en contra de ambos.

Paralelamente se realizó una investigación penal de la alegada desaparición y tortura de Juan Arrom y Anuncio Martí, en la cual se llevaron a cabo múltiples diligencias tendientes a indagar lo sucedido. Entre ellas, se pueden mencionar las siguientes: a) inspección de la casa dónde fueron encontrados Juan Arrom y Anuncio Martí; b) allanamiento de otra casa, donde presuntamente habrían estado detenidas las presuntas víctimas los primeros días; c) recepción de las declaraciones del Ministro del Interior, del Ministro de Justicia y Trabajo, del Fiscal General, de tres fiscales, de al menos 16 oficiales de policías y 87 declaraciones de personas que podrían tener información sobre lo sucedido, o de los posibles implicados; d) reconstrucción de los hechos del momento de la presunta detención de Juan Arrom y Anuncio Martí; e) reconstrucción de los hechos del momento del hallazgo de Juan Arrom y Anuncio Martí , y f) identikit en base a lo dicho por Juan Arrom. Después de esta investigación se dictó el sobreseimiento definitivo de los imputados y se desestimaron las querellas presentadas, lo cual fue confirmado el 24 de marzo de 2004 por la Sala Cuarta del Tribunal de Apelaciones en lo Penal.

\section{Fondo}
A). Alegada violación de los derechos a la libertad personal, integridad personal, vida y reconocimiento de la personalidad jurídica, en relación con la obligación de respetar los derechos 
Tomando en cuenta que la controversia del presente caso consistía en la participación o no de agentes estatales en la alegada desaparición y tortura de Juan Arrom y Anuncio Martí, la Corte procedió a analizar si estos hechos alegados podían ser atribuidos al Estado paraguayo.

La Corte constató que, a diferencia de otros casos conocidos por este Tribunal, este no se enmarcó dentro de un contexto de práctica sistemática y generalizada de desapariciones forzadas, persecución política u otras violaciones de derechos humanos, por lo que no era posible utilizar el mismo para corroborar otros elementos de prueba. Asimismo, la Corte señalo que en el presente caso no existió prueba que demostrara que las presuntas víctimas estuvieron en manos de agentes del Estado antes de que sucedieran los hechos alegados. Por tanto, el Tribunal consideró que no era aplicable una presunción en contra del Estado en relación con lo sucedido. Además, los elementos de prueba presentados por los representantes y la Comisión se referían primordialmente a la alegada participación de determinados agentes del Estado identificados por las presuntas víctimas, quienes fueron investigados por las autoridades internas.

Tras analizar el acervo probatorio del caso, la Corte advirtió que la gran mayoría de las pruebas presentadas se referían a declaraciones de las presuntas víctimas y testimonios de oídas, los cuales para ser concluyentes en relación a la responsabilidad internacional del Estado debían coincidir con otros elementos de prueba. Las investigaciones realizadas internamente tomaron en cuenta dichas declaraciones, así como los elementos de prueba que demostrarían la no participación de las personas individualizadas por las presuntas víctimas y concluyeron que no se contaban con elementos suficientes para presentar una acusación en contra de ellas. Asimismo, el Tribunal señaló que en el expediente ante la Corte no obraban elementos adicionales a los examinados por las autoridades internas que demostraran la participación estatal.

En virtud de las consideraciones anteriores, la Corte consideró que los indicios presentados ante ella eran insuficientes para concluir que los señores Juan Arrom Suhurt y Anuncio Martí Méndez fueron privados de libertad por parte de agentes estatales o con la aquiescencia de estos. Por tanto, la Corte concluyó que el Estado no es responsable de la violación de los artículos 3, 4, 5 y 7 de la Convención, en relación con el artículo I.a) de la Convención Interamericana sobre Desaparición 
Forzada de Personas y de los artículos 1 y 6 de la Convención Interamericana para Prevenir y Sancionar la Tortura.

\section{B. Alegada violación de los derechos a las garantías judiciales y a la protección judicial, en relación con la obligación de respetar y garantizar los derechos}

En cuanto al deber de iniciar de oficio una investigación, la Corte recordó que este caso no se enmarcó en un contexto de práctica sistemática y generalizada de desaparición forzada, persecución política u otras violaciones de derechos humanos ni tampoco existía prueba alguna que demostrara que las presuntas víctimas estuvieron en manos de agentes del Estado antes de que sucedieran los hechos alegados. Por ende, la Corte señaló que una vez recibida la información solicitada por los jueces a cargo de los hábeas corpus, no existían motivos razonables para sospechar que Juan Arrom Suhurt y Anuncio Martí Méndez habían sido víctimas de una desaparición forzada. Por otra parte, la Corte advirtió que en el presente caso era un hecho público y notorio que en los mismos días que el Estado tuvo conocimiento sobre la desaparición de las presuntas víctimas, este ya estaba realizado diversas acciones de búsqueda para determinar su paradero con el objeto de poder hacer efectiva su orden de detención. Por tanto, para el Tribunal resultaría contradictorio considerar que las autoridades estatales no estaban realizando acciones de búsqueda para dar con el paradero de Juan Arrom Suhurt y Anuncio Martí Méndez. En consecuencia, la Corte concluyó que el Estado no incumplió con su obligación de iniciar sin dilación y de oficio la investigación de la desaparición de Juan Arrom Suhurt y Anuncio Martí Méndez. Asimismo, tampoco se configuró una violación del artículo 25 de la Convención por la alegada inefectividad de los hábeas corpus presentados.

En cuanto a la debida diligencia en las investigaciones, la Corte resaltó que se desprende del acervo probatorio que las autoridades encargadas de la investigación sobre la alegada desaparición y tortura de las presuntas víctimas realizaron múltiples diligencias tendientes a indagar lo sucedido. Los 
representantes presentaron una lista de diligencias y alegaron que no se habrían realizado dentro de la investigación. Al respecto, la Corte hizo notar que al menos 19 diligencias que los representantes listaron como no realizadas sí se llevaron a cabo dentro de la investigación, y que otras diligencias no se efectuaron por falta de colaboración de las presuntas víctimas o sus representantes.

En virtud de las consideraciones anteriores, la Corte consideró que no era posible determinar que las presuntas omisiones señaladas por los representantes y la Comisión resultaran suficientes para configurar la responsabilidad internacional del Estado.

Por las razones anteriores la Corte concluyó que el Estado no era responsable de una violación de los artículos 8.1 y 25.1 de la Convención, en relación con el artículo 1.1 del mismo instrumento, el artículo I.b) de la Convención Interamericana sobre Desaparición Forzada, y los artículos 1, 6 y 8 de la Convención Interamericana para Prevenir y Sancionar la Tortura.

\section{Alegada violación del derecho a la integridad personal de los familiares de Juan Arrom y Anuncio Martí}

La Corte hizo notar que las argumentaciones sobre la alegada violación del derecho a la integridad personal de los familiares se fundamentaron en la supuesta responsabilidad estatal por la desaparición forzada de Juan Arrom Suhurt y Anuncio Martí, o en la aducida falta de investigación adecuada de los hechos. La Corte consideró que el Estado no era internacionalmente responsable respecto a la alegada violación del derecho mencionado, consagrado en el artículo 5 de la Convención Americana, en tanto no estableció la participación estatal en la alegada desaparición y tortura de Juan Arrom Suhurt y Anuncio Martí Méndez, ni por una violación a los derechos a las garantías y protección judiciales. 